Primljeno: 24/10/2019

UDK: 378-051:37.091.33-028.27

Izvorni znanstveni rad

\title{
VAŽNOST RAZVOJA KOMPETENCIJA
} ZA E-UČENJE KOD VISOKOŠKOLSKIH NASTAVNIKA ZA PRIMJENU HIBRIDNOGA OKRUŽENJA ZA UČENJE

\author{
Snježana Babić \\ Veleučilište u Rijeci \\ snjezana.babic@veleri.hr \\ Darko Etinger \\ Fakultet informatike \\ Sveučilište Jurja Dobrile u Puli
}




\section{SAŽETAK}

Pod utjecajem različitih aspekata visokoškolske ustanove sve više ulažu u razvoj različitih modela e-obrazovanja, među kojima su hibridna okruženja za učenje. Rezultati prijašnjih istraživanja pokazali su da usvajanje e-učenja kod visokoškolskih nastavnika ovisi o razini njihovih kompetencija za e-učenje. Ciljovoga rada bio je ukazati na važnost razvoja kompetencija za e-učenje kod visokoškolskih nastavnika za primjenu hibridnih okruženja za učenje kroz prikaz rezultata istraživanja na Fakultetu informatike Sveučilišta u Puli. Rezultati istraživanja u ovome radu pokazali su da se visokoškolski nastavnici koji su korisnici e-učenja u najvećoj mjeri samoeduciraju za e-učenje, raspolažu s visokom razinom IKT znanja i vještina te nemaju dovoljno pedagoških znanja za primjenu hibridnoga okruženja za učenje na naprednijoj razini. Dobivene rezultate mogu upotrijebiti svi oni kojima je interes razvoj e-obrazovanja na visokoškolskim ustanovama $i$ šire.

Ključne riječi: visokoškolski nastavnici, ICT znanja i vještine, pedagoška kompetencija za e-učenje, hibridno okruženje za učenje. 


\section{UVOD}

Razina usvajanja tehnologije za e-učenje od strane visokoškolskih nastavnika je jedan od glavnih činitelja koji utječu na razvoj kvalitete korištenja e-obrazovanja u visokoškolskim obrazovnim sustavima. Hibridno okruženje za učenje jedan je od najčešće korištenih oblika e-učenja koji se može realizirati u nastavi u različitim modelima, ovisno o količini zastupljenosti online nastavnih aktivnosti koje se izvode pomoću tehnologije za e-učenje, odnosno sustava za e-učenje, u odnosu na nastavne aktivnosti koje se izvode u tradicionalnoj učionici. Samo malim pomakom naglašavanja uloge nastavnika, obrazovnoga sadržaja ili studenata u hibridnoj nastavi očekuje se da visokoškolski nastavnik primjeni drugu razinu kompetencije za e-učenje. Tako nastavnik može mijenjati uloge od one u kojoj samo prenosi obrazovni sadržaj, zatim uloge u kojoj stvara online zajednice učenja do uloge posrednika koji potiče i pomaže studente pri suradničkoj izgradnji novih znanja u virtualnim okruženjima. U odnosu na čisto online poučavanje, visokoškolski nastavnik pri poučavanju u hibridnom okruženju mora se dodatno koristiti znanjima, vještinama i sposobnostima za povezivanje nastavnih aktivnosti koje izvodi u hibridnome okruženju s nastavnim aktivnostima u tradicionalnoj učionici. U osnovi e-učenje spaja dvije dimenzije: pedagogiju i tehnologiju. Stoga se kompetencije visokoškolskih nastavnika za primjenu e-učenja u hibridnome okruženju mogu promatrati kroz te dvije dimenzije. Tehnička dimenzija kompetencija za e-učenje uključuje znanja, vještine i sposobnosti koje su potrebne visokoškolskim nastavnicima za rad s tehnologijom za e-učenje, odnosno sustavom za e-učenje i drugom informacijsko-komunikacijskom tehnologijom, dok pedagoška dimenzija kompetencija za e-učenje uključuje znanja, vještine i sposobnosti koje su potrebne za izvođenje pojedinih faza nastavnoga procesa. Visokoškolski nastavnici koji posjeduju tehničku kompetenciju za e-učenje mogu razumjeti pedagoško korištenje IKT-a u nastavnome procesu, uz uvjet da imaju odgovarajuća pedagoška znanja (Babić, 2016).

Prema Rogersu (1995) svaka inovacija ima svoj tijek prihvaćanja te je potrebno određeno vrijeme kada će je većina korisnika prihvatiti. Međutim, nakon prihvaćanja inovacije, javlja se izazov razine usvajanja inovacija kod korisnika. S obzirom na promjene užega i širega okruženja te na specifičnosti pojedinih obrazovnih sustava, potreba za istraživanjem činitelja koji utječu na razinu usvajanja e-učenja u visokoškolskim ustanovama uvijek je iznova otvorena. Posebno, u ovome radu naglasak je stavljen na važnost kompetencija visokoškolskih nastavnika za e-učenje u hibridnome okruženju za učenje. 


\section{PRIHVAĆANJE E-UČENJA I KOMPETENCIJE VISOKOŠKOLSKIH NASTAVNIKA ZA NJEGOVU PRIMJENU U HIBRIDNOME OBLIKU}

Prema rezultatima istraživanja, koje su proveli Ehlers i Kellermann (2019) kod 53 međunarodna eksperta, sljedeće su četiri značajne promjene koje će oblikovati revoluciju učenja i poučavanja u visokoškolskome obrazovnom sustavu: (a) razvoj sposobnosti studenata za uspješno djelovanje na složenome problemu u nepoznatome okruženju u budućnosti (tzv. „future skills"), (b) „multiinstitucionalni“ modeli visokoškolskih institucija - umreženo studijsko iskustvo, (c) scenarij „moje sveučilište" u okviru kojega studenti mogu samostalno uz podršku nastavnika izgraditi nastavne planove i programe visokoga obrazovanja i (d) kontinuirano cjeloživotno visoko obrazovanje. U okviru navedenih scenarija posebno je važna promjena uloga visokoškolskih nastavnika koja se sve više mijenja u „pomagače“ u procesu učenja i poučavanja. Stoga Ehlers i Kellermann (2019) ističu važnost promjene pedagoškoga oblikovanja akademskoga učenja i poučavanja (inovativne procjene znanja, razvoj tzv. „zajednica učenja“, razvoj suradničkih okruženja i drugo) koja imaju važnu ulogu u interaktivnim društveno-konstruktivističkim okruženjima za učenje. Ehlers i Kellermann (2019) ukazuju na to da je za promjenu kulture visokoškolskih institucija strateški važna osposobljenost akademskoga osoblja, odnosno razvoj njihovih znanja, vještina i sposobnosti te njihova motivacija za nove metode poučavanja, za što su potrebna dodatna stručna usavršavanja.

Nadalje, rezultati analize strategija visokoškolskih institucija, koje je proveo (Altin, 2019) na njemačkim visokoškolskim učilištima, pokazuju da stvaranje „fleksibilnijih programa“ (posebno s e-učenjem) doprinosi njihovoj većoj konkurentnosti na međunarodnim tržištima. Internacionalizacija obrazovnih programa jedan je od najvažnijih izazova u visokome obrazovanju u kojem primjena e-obrazovanja još više dobiva na važnosti. Međutim, Jokiaho i sur. (2018) ističu da se u većini visokoškolskih institucija diljem Europe javlja izazov nedovoljne iskoristivosti punoga potencijala e-obrazovanja, što usporava implementaciju inovativnih tehnologija i pedagoških scenarija, kao i novih oblika obrazovanja, poput otvorenih obrazovnih resursa (eng. Open Educational Resources - OER) i masovnih otvorenih online tečajeva (eng. Massive Open Online Course - MOOC). Iz navedenoga slijedi da je pitanje razloga nekorištenja pedagoškoga potencijala e-učenja uvijek iznova otvoreno pitanje za mnoge visokoškolske ustanove.

U ovome je radu posebno naglašen hibridni oblik nastave kao jedan od najviše zastupljenih modela e-učenja na visokoškolskim ustanovama. „Hibridno okruženje za učenje sustavno je modelirano obrazovno okruženje u kojem se na osnovi 
potreba i karakteristika užeg obrazovnog okruženja (studenata i obrazovnog sadržaja) i šireg (institucija) obavlja izbor i povezivanje nastavnih aktivnosti u tradicionalnoj učionici (sa ili bez uporabe tehnologije) s online nastavnim aktivnostima u virtualnom okruženju za učenje (sustavu za e-učenje) uz obveznu interakciju u cilju uspješne realizacije obrazovnog cilja." (Babić, 2016, 9). Važno je naglasiti da uporaba sustava za e-učenje u nastavnome procesu ima pozitivan utjecaj na studensko učenje i motivaciju (Burac i sur., 2019).

Kao što je već naglašeno, prihvaćanje te razina usvajanja e-učenja od strane visokoškolskih nastavnika jedan je od ključnih činitelja razvoja e-obrazovanja u svim visokoškolskim obrazovnim institucijama. Brojni istraživači ukazali su na brojne činitelje koji utječu na navedeno, kao primjer rezultati istraživanja koje su proveli Martín-García i suradnici (2019) kod 980 visokoškolskih nastavnika u okviru 43 javna sveučilišta u Španjolskoj potvrđuju da je namjera korištenja hibridnoga učenja najvažnija varijabla predviđanja u svim njegovim primijenjenim modelima. Nadalje, potvrđena je povezanost između viših razina primjene metodologije hibridnoga učenja s iskustvom u digitalnim obrazovnim okruženjima i većom učestalosti njihova korištenja od strane nastavnika. Osim toga, kod nastavnika su potvrđene i sljedeće barijere implementacije e-učenja u visokoškolski nastavni proces: dostupnost alata za e-učenje, pedagoška i tehnička podrška, nedostatak vremena, samoučinkovitost, nedostatak vidljivosti uloženog truda, prilagođavanje obrazovnog sadržaja prema karakteristikama studenata, inovativnost $u$ korištenju IKT, osobne karakteristike nastavnika, jednostavnost pristupa, podrška $i$ obuka, pedagoška znanja, strah od tehnologije i drugo (Babić, 2009; Babić i Bubaš, 2015; Babić, 2016; Jokiaho i sur., 2018; Gunasinghe, i sur., 2018; Alhabeeb i Rowley, 2018; Bierne i sur., 2018; Sinclair i Aho, 2018; Akar i Güzin, 2019). Rezultati studije Al-Samarraie i sur. (2018) pokazuju da kvaliteta informacija, aktivnost koja se izvodi uz pomoć tehnologije, kvaliteta sustava i korisnost utječu na zadovoljstvo korisnika e-učenja i njihovo kontinuirano korištenje e-učenja u nastavi. Akar i Güzin (2019) su potvrdili da se povećanje razine percepcije nastavnika o korisnosti i jednostavnosti korišstenja tehnologije, zatim razine samoefikasnosti nastavnika u pogledu korištenja tehnologije i smanjenjem računalne anksioznosti dovodi do više razine njihova pedagoškoga korištenja tehnologije.

Kao primjer, Babić i Bubaš (2015) definirali su konceptualni model kompetencija nastavnika za primjenu online učenja, i to na osnovi višegodišnjega iskustva u primjeni e-učenja, iscrpne teorijske analize, modela prihvaćanja tehnologije i inovacija, rezultata istraživanja u stvarnome visokoškolskome obrazovnom okruženju te sljedećih odabranih razvijenih standarda, okvira i indikatora: "European Pedagogical ICT Licence - EPICT” (http://www.epict.org); “Teacher ICT Com- 
petency Framework - eTQF" (http://etqfproject.ning.com); "Guidelines for Professional Development of Online Teachers" (http://www.sreb.org); "ISTE/NETS for Teachers" (http://www.iste.org); "The eLearning Competency Framework for Teachers and Trainer" (EIfEL standard, http://www.eife-l.org); "Common European Framework uTeacher" (http://www.egger.ac/1docs/booklet2b.pdf); "Blended Learning Certificate" (http://www.astd.org); "Certificate in e-Learning Design" (http://www.tap-training.com). Navedeni konceptualni model uključuje četiri kategorije: (1) znanje, vještine, sposobnosti, stavovi i vrijednosti za implemetaciju informacijsko-komunikacijske tehnologije (IKT) i obrazovne tehnologije u hibridnom visokoškolskom okruženju; (2) osobne karakteristike nastavnika; (3) situacijski činitelji i (4) institucijski činitelji - organizacijska kultura. Njihovi rezultati istraživanja također pokazuju da su znanja, vještine i sposobnosti za primjenu IKT-a u hibridnoj nastavi glavna barijera prihvaćanja hibridnoga oblika eučenja od strane visokoškolskih nastavnika, pri čemu IKT znanja i vještine utječu na razumijevanje pedagoških znanja korištenja hibridnih oblika e-učenja (Babić, 2016). Prema rezultatima istraživanja koje je provela Babić (2016) oni visokoškolski nastavnici $(\mathrm{N}=271)$ koji se koriste e-učenjem u hibridnome okruženju na višoj i naprednoj razini imaju višu razinu IKT znanja i vještina te višu razinu pedagoških kompetencija za primjenu IKT u hibridnoj nastavi.

\section{METODOLOGIJA ISTRAŽIVANJA}

U ovome je radu cilj istraživanja bio ispitati percepciju visokoškolskih nastavnika Fakulteta informatike Sveučilišta u Puli o njihovim tehničkim i pedagoškim znanjima, vještinama i sposobnostima korištenja hibridnoga oblika nastave, kao najznačajnijim barijerama u usvajanju hibridnoga okruženja za učenje vezanih uz kompetenciju nastavnika za e-učenje.

\subsection{Procedura i korišteni instrumenti u istraživanju}

Istraživanje je provedeno u srpnju 2019. godine na Fakultetu informatike Sveučilišta u Puli. Fakultet osigurava svim nastavnicima i studentima podršku i obrazovne sadržaje za tehničko korištenje sustava za e-učenje te nema definiranu strategiju za e-učenje.

Korištena je metoda anketnoga upitnika, a instrument je bio pripremljen $\mathrm{u}$ online obliku pomoću aplikacije Kwiksurveys te zasnovan na dobrovoljnoj i anonimnoj razini. Za potrebe ovoga istraživanja korišten je upitnik kojega su razvili Babić i Bubaš (2015) i Babić (2016). Upitnik je sadržavao 113 pitanja u okviru dva 
dijela. U prvome su se dijelu nalazile čestice za prikupljanje podataka o demografskim karakteristikama nastavnika te o njihovome iskustvu u korištenju tehnologije za e-učenje. Drugi se dio upitnika sastojao od 15 skala za samoprocjenu koje su vezane uz kompetencije za e-učenje i druge činitelje prihvaćanja e-učenja. Odgovore su visokoškolski nastavnici mogli dati na Likertovoj ljestvici od 5 stupnjeva (1 $=$ potpuno netočno do $5=$ potpuno točno).

U ovome su radu prezentirani samo rezultati koji se odnose na odabrane demografske karakteristike i načine korištenja pojedine tehnologije te dvije skale „IKT znanja i vještine“ $\mathrm{i}$ „pedagoška kompetencija za primjenu IKT u hibridnoj nastavi“.

\subsection{Ispitanici}

Ispitanici su u ovome istraživanju bili 11 visokoškolskih nastavnika Fakulteta informatike u Puli koji su svi upotrebljavali fakultetski sustav za e-učenje u hibridnome okruženju u svojoj nastavi, pri čemu su ga u najvećoj mjeri koristili za dijeljenje nastavnih materijala studentima, online komunikaciju (e-pošta i forum) sa studentima za davanje osnovnih informacija o kolegiju te osnovnih oblika online procjena znanja. Uzorak je činila većina visokoškolskih nastavnika (90,9 \%) koji su bili stručnjaci u informatici.

Među ispitanicima je najzastupljenija skupina onih visokoškolskih nastavnika koji su imali između 30 i 50 godina starosti (73\%), dok je najmanje ispitanika (27 \%) imalo više od 50 godina starosti. Malo više od polovine ispitanika (55 \%) čine nastavnici koji su imali 15 i manje godina nastavnoga iskustva, zatim njih $36 \%$ su imali između 20 i 30 godina nastavnoga iskustva te je samo 1 nastavnik imao više od 30 godina nastavnoga iskustva. Rezultati pokazuju da u odnosu na znanstveno područje u uzorku ispitanika u ovome istraživanju najviše visokoškolskih nastavnika pripada društvenom području znanosti (73\%), zatim tehničkom području znanosti (18 \%) i prirodnim područjima (1 \%). Najviše ispitanika (45 \%) bilo je sa zvanjem docenta, zatim $27 \%$ izvanrednih profesora, $18 \%$ asistenta, $1 \%$ predavača i $1 \%$ viših predavača. Najviše ispitanika, njih $82 \%$, imalo je najviši akademski stupanj doktora znanosti, njih $18 \%$ imalo je sveučilišni ili stručni stupanj magistara struke, dok je najmanje njih, $1 \%$, imalo stupanj magistra znanosti.

Ispitanici su znanje iz e-obrazovanja ocijenili u prosjeku vrlo dobrom ocjenom $(\mathrm{M}=3.73 ; \delta=0.90)$ na skali od $1=$ vrlo slabo do $5=$ izvrsno. Među ispitanicima njih $2(18,2 \%)$ procjenjuje svoje znanje iz e-obrazovanja kao izvrsno, dok se njih 3 (27,3 \%) izjasnilo da ima dobro znanje i samo se 1 sudionik (1 \%) izjasnilo da ima slabo znanje. 
S obzirom na način edukacije za upotrebu e-učenja u nastavi jednaki broj ispitanika, njih 5 (45,5 \%) se educiralo samo za korištenje tehničkih funkcionalnosti tehnologija i alata za e-učenje i njih 5 (45,5\%) za korištenje tehničkih funkcionalnosti tehnologije i alata za e-učenje i pedagoških sadržaja vezanih uz njihovu primjenu u nastavnom procesu, dok se samo 1 ispitanik educirao samo iz područja pedagogije za primjenu tehnologije i alata za e-učenje u nastavi.

Kao što je prikazano na Grafu 1., na pitanje o obliku stjecanja znanja, vještina i sposobnosti iz područja e-obrazovanja više od polovine ispitanika, njih 6 (55\%), se izjasnilo da su znanja, vještine i sposobnosti iz područja e-obrazovanja stjecali samoedukacijom koristeći dostupne vodiče, literaturu i primjere dobre prakse te njih $36,4 \%$ je stjecalo znanja iz e-obrazovanja na organiziranim radionicama i tečajevima.

Graf 1.: Struktura ispitanika s obzirom na oblik stjecanja znanja, vještina i sposobnosti iz područja e-obrazovanja

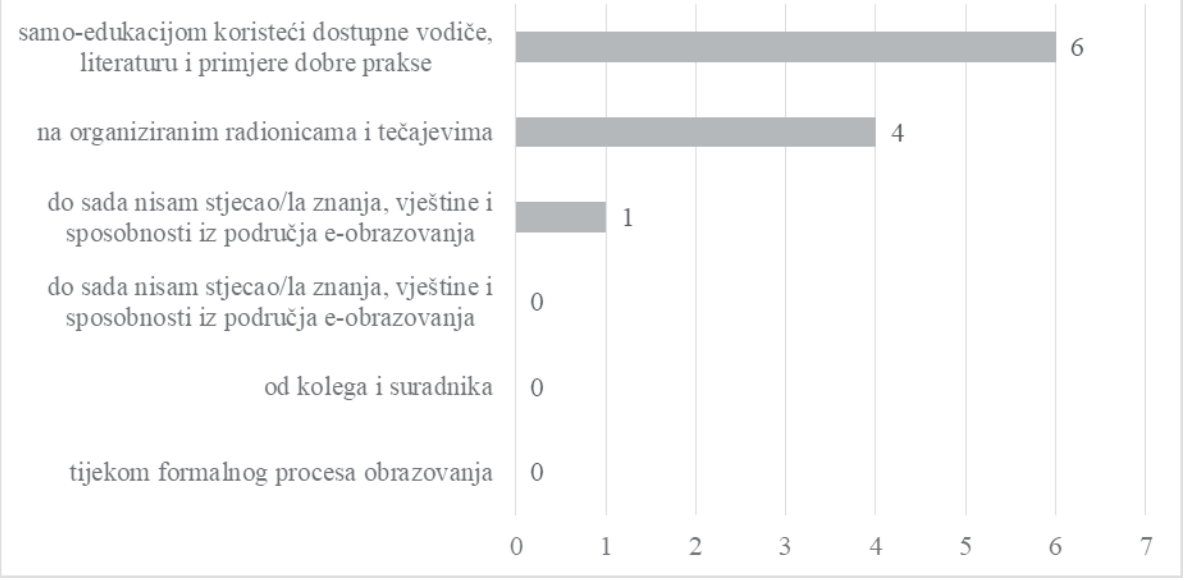

Osim toga, većina ispitanika, njih 6 (54,5\%) je dosad izradilo jedan do pet jednostavnih online tečaja/kolegija za potrebe svojega nastavnog rada, zatim njih 2 $(18,2 \%)$ su izradili više dobro strukturirane online tečajeve prema nekom modelu instrukcijskoga dizajna te se njih 3 (27,3\%) izjasnilo da dotad nije izradilo niti jedan online tečaj/kolegij.

Prema osnovnim deskriptivnim podacima vezanim uz intenzitet korištenja pojedine internetske tehnologije (ili alata) za potrebe e-učenja ili nastave na tjednoj razini kod ispitanika (Tablica 1.) vidljivo je da su se ispitanici na tjednoj razini koristili sljedećim internetskim tehnologijama (ili alatima) za potrebe e-učenja ili nastave (silaznim redoslijedom prema udjelu ispitanika): 1. elektroničku poštu 
(100,0 \%), 2. sustav e-učenja (Moodle; $90.9 \%)$, 3. multifunkcionalne alate (81,8 \%), 4. online videozapise (YouTube) (72,7 \%), 5. wiki, blog i slične alate (63,6 \%), 6. forumske rasprave (54,5\%), 7. online testove (Hot Potatoes) (45,5\%), 8. društvene mreže (Facebook) (36,4 \%) i 9. videokonferencije i webinare i online ankete (SurveyMonkey) (27,3\%).

Tablica 1.: Broj (postotak) ispitanika vezan uz intenzitet korištenja pojedine internetske tehnologije za potrebe e-učenja ili nastave na tjednoj razini kod ispitanika - visokoškolskih nastavnika

\begin{tabular}{|c|c|c|c|c|c|c|c|}
\hline \multirow{2}{*}{$\begin{array}{l}\text { Internetske } \\
\text { tehnologije }\end{array}$} & \multicolumn{7}{|c|}{ Postotak ispitanika vezan uz intenzitet korištenja (\%) } \\
\hline & $\begin{array}{l}\text { Ne kori- } \\
\text { stim se }\end{array}$ & do 1 sat & $2-3$ sata & $4-5$ sati & 6-7 sati & $8-9$ sati & $\begin{array}{l}10 \text { i više } \\
\text { sati }\end{array}$ \\
\hline Elektronička pošta & $\begin{array}{c}0 \\
(0,0) \\
\end{array}$ & $\begin{array}{c}2 \\
(18,2)\end{array}$ & $\begin{array}{c}3 \\
(27,3)\end{array}$ & $\begin{array}{c}1 \\
(9,1)\end{array}$ & $\begin{array}{c}1 \\
(9,1)\end{array}$ & $\begin{array}{c}0 \\
(0,0) \\
\end{array}$ & $\begin{array}{c}4 \\
(36,3)\end{array}$ \\
\hline Forumske rasprave & $\begin{array}{c}5 \\
(45,5) \\
\end{array}$ & $\begin{array}{c}4 \\
(36,3) \\
\end{array}$ & $\begin{array}{c}1 \\
(9,1) \\
\end{array}$ & $\begin{array}{c}1 \\
(9,1) \\
\end{array}$ & $\begin{array}{c}0 \\
(0,0) \\
\end{array}$ & $\begin{array}{c}0 \\
(0,0) \\
\end{array}$ & $\begin{array}{c}0 \\
(0,0) \\
\end{array}$ \\
\hline $\begin{array}{l}\text { Videokonferencije i } \\
\text { webinari }\end{array}$ & $\begin{array}{c}8 \\
(72,7) \\
\end{array}$ & $\begin{array}{c}2 \\
(18,2) \\
\end{array}$ & $\begin{array}{c}1 \\
(9,1) \\
\end{array}$ & $\begin{array}{c}0 \\
(0,0) \\
\end{array}$ & $\begin{array}{c}0 \\
(0,0) \\
\end{array}$ & $\begin{array}{c}0 \\
(0,0) \\
\end{array}$ & $\begin{array}{c}0 \\
(0,0) \\
\end{array}$ \\
\hline $\begin{array}{l}\text { Online videozapise } \\
\text { (YouTube) }\end{array}$ & $\begin{array}{c}3 \\
(27,3) \\
\end{array}$ & $\begin{array}{c}5 \\
(45,5) \\
\end{array}$ & $\begin{array}{c}1 \\
(9,1)\end{array}$ & $\begin{array}{c}2 \\
(18,2)\end{array}$ & $\begin{array}{c}0 \\
(0,0) \\
\end{array}$ & $\begin{array}{c}0 \\
(0,0) \\
\end{array}$ & $\begin{array}{c}0 \\
(0,0) \\
\end{array}$ \\
\hline Wiki, blog i sl. alati & $\begin{array}{c}4 \\
(36,3) \\
\end{array}$ & $\begin{array}{c}5 \\
(45,5) \\
\end{array}$ & $\begin{array}{c}1 \\
(9,1) \\
\end{array}$ & $\begin{array}{c}1 \\
(9,1) \\
\end{array}$ & $\begin{array}{c}0 \\
(0,0) \\
\end{array}$ & $\begin{array}{c}0 \\
(0,0) \\
\end{array}$ & $\begin{array}{c}0 \\
(0,0) \\
\end{array}$ \\
\hline $\begin{array}{l}\text { Društvene mreže } \\
\text { (Facebook) }\end{array}$ & $\begin{array}{c}7 \\
(63,6)\end{array}$ & $\begin{array}{c}2 \\
(18,2)\end{array}$ & $\begin{array}{c}1 \\
(9,1)\end{array}$ & $\begin{array}{c}1 \\
(9,1)\end{array}$ & $\begin{array}{c}0 \\
(0,0)\end{array}$ & $\begin{array}{c}0 \\
(0,0)\end{array}$ & $\begin{array}{c}0 \\
(0,0)\end{array}$ \\
\hline $\begin{array}{l}\text { Sustavi za e-učenje } \\
\text { (Moodle) }\end{array}$ & $\begin{array}{c}1 \\
(9,1)\end{array}$ & $\begin{array}{c}4 \\
(36,3)\end{array}$ & $\begin{array}{c}2 \\
(18,2)\end{array}$ & $\begin{array}{c}0 \\
(0,0)\end{array}$ & $\begin{array}{c}4 \\
(36,4)\end{array}$ & $\begin{array}{c}0 \\
(0,0)\end{array}$ & $\begin{array}{c}0 \\
(0,0)\end{array}$ \\
\hline $\begin{array}{l}\text { Multifunkcionalni } \\
\text { alati (Google Drive) }\end{array}$ & $\begin{array}{c}2 \\
(18,2)\end{array}$ & $\begin{array}{c}2 \\
(18,2)\end{array}$ & $\begin{array}{c}2 \\
(18,2)\end{array}$ & $\begin{array}{c}3 \\
(27,3)\end{array}$ & $\begin{array}{c}2 \\
(18,2)\end{array}$ & $\begin{array}{c}0 \\
(0,0)\end{array}$ & $\begin{array}{c}0 \\
(0,0)\end{array}$ \\
\hline $\begin{array}{l}\text { Online ankete } \\
\text { (SurveyMonkey) }\end{array}$ & $\begin{array}{c}8 \\
(72,7) \\
\end{array}$ & $\begin{array}{c}1 \\
(9,1)\end{array}$ & $\begin{array}{c}1 \\
(9,1)\end{array}$ & $\begin{array}{c}1 \\
(9,1)\end{array}$ & $\begin{array}{c}0 \\
(0,0)\end{array}$ & $\begin{array}{c}0 \\
(0,0) \\
\end{array}$ & $\begin{array}{c}0 \\
(0,0) \\
\end{array}$ \\
\hline $\begin{array}{l}\text { Online testovi (Hot } \\
\text { Potatoes) }\end{array}$ & $\begin{array}{c}6 \\
(54,5)\end{array}$ & $\begin{array}{c}3 \\
(27,3)\end{array}$ & $\begin{array}{c}2 \\
(18,2)\end{array}$ & $\begin{array}{c}0 \\
(0,0)\end{array}$ & $\begin{array}{c}0 \\
(0,0)\end{array}$ & $\begin{array}{c}0 \\
(0,0)\end{array}$ & $\begin{array}{c}0 \\
(0,0)\end{array}$ \\
\hline
\end{tabular}

\section{REZULTATI I RASPRAVA}

Prema dobivenih aritmetičkim sredinama u rasponu od $M=4,1$ do $M=4,6$ (Tablica 1.) vidljivo je kako se visokoškolski nastavnici Fakulteta informatike u Puli u prosjeku slažu da posjeduju dovoljno IKT znanja i vještina. Većina ispitanika, njih $8(72,7 \%)$ se u potpunosti slaže da posjeduju dovoljno osnovnih računalnih vještina te da su u mogućnosti nesmetano raditi računalom, zatim njih 10 $(90,9 \%)$ je izjavilo da su sposobni koristiti se različitim osnovnim i naprednim 
alatima za izradu digitalnoga zapisa sadržaja. Nešto manje ispitanika (7; 63,6 \%) se u potpunosti slaže da je sposobno koristiti se internetskim alatima za komunikaciju i suradnju (forum, pričaonica/chat, videokonferenciju, webinar, e-portfolio, društveni softver, wiki, blog i druge web 2.0 alate). Zanimljivo je da je samo malo više od polovine ispitanike (54,5\%) izjavilo da se u potpunosti slaže da su sposobni koristiti se osnovnim i naprednim alatima za izradu multimedijalnoga sadržaja (grafički prikaz, audio i videozapise, simulacije i sl.). Navedeni su rezultati bili očekivani s obzirom na to da su većina ispitanika stručnjaci u informatici. Navedeno ukazuje da ispitanici raspolažu s dovoljno IKT znanja i vještina, što je osnova za primjenu e-učenja.

Tablica 2.: Broj (postotak) odgovora ispitanika (na stupnjevima od 1 - potpuno netočno do 5 - potpuno točno), aritmetička sredina (M) i standardna devijacija (s) vezana uz skalu „IKT znanja i vještine“

$\begin{array}{lllllllll}\text { Tvrdnje } & 1 & 2 & 3 & 4 & 5 & \begin{array}{c}M \\ (\delta)\end{array}\end{array}$

Smatram da posjedujem dovoljno osnovnih računalnih vještina te sam u mogućnosti nesmetano raditi računalom (npr. ukloniti probleme s dijelovima računala, nadograditi računalo računalnim programima, riješiti pitanje

$\begin{array}{cccccc}1 & 0 & 1 & 1 & \mathbf{8} & 4,4 \\ (9,1) & (0,0) & (9,1) & (9,1) & (72,7) & (1,3)\end{array}$
sigurnosti i zaštite podataka i sl.).

\begin{tabular}{|c|c|c|c|c|c|c|}
\hline $\begin{array}{l}\text { Sposoban/sposobna sam koristiti se različitim } \\
\text { osnovnim i naprednim alatima za izradu } \\
\text { digitalnoga zapisa sadržaja (tekst procesore, } \\
\text { prezentacijski softver, proračunske tablice i sl.). }\end{array}$ & $\begin{array}{c}1 \\
(9,1)\end{array}$ & $\begin{array}{c}0 \\
(0,0)\end{array}$ & $\begin{array}{c}0 \\
(0,0)\end{array}$ & $\begin{array}{c}0 \\
(0,0)\end{array}$ & $\begin{array}{c}10 \\
(90,9)\end{array}$ & $\begin{array}{c}4,6 \\
(1,2)\end{array}$ \\
\hline $\begin{array}{l}\text { Sposoban/sposobna sam koristiti se različitim } \\
\text { osnovnim i naprednim alatima za izradu } \\
\text { multimedijalnoga sadržaja (grafički prikaz, audio i } \\
\text { videozapise, simulacije i sl.) }\end{array}$ & $\begin{array}{c}0 \\
(0,0)\end{array}$ & $\begin{array}{c}1 \\
(9,1)\end{array}$ & $\begin{array}{c}3 \\
(27,3)\end{array}$ & $\begin{array}{c}1 \\
(9,1)\end{array}$ & $\begin{array}{c}6 \\
(54,5)\end{array}$ & $\begin{array}{c}4,2 \\
(1,1)\end{array}$ \\
\hline
\end{tabular}

Sposoban/sposobna sam koristiti se mnogim internetskim alatima za komunikaciju, suradnju i organizaciju online informacija (npr. forum, pričaonica/chat, videokonferenciju, webinar, e-portfolio, društveni softver, wiki, blog, i druge

$\begin{array}{cccccc}0 & 1 & 3 & 0 & 7 & 4,2 \\ (0,0) & (9,1) & (27,3) & (0,0) & (\mathbf{6 3 , 6}) & (1,2)\end{array}$
web 2.0 alate).

U Tablici 3. je usporedni prikaz postotaka odgovora sudionika na navedenoj skali te aritmetičke sredine i standardne devijacije. Prema dobivenih aritmetičkim sredinama vidljivo je kako visokoškolski nastavnici Fakulteta informatike u Puli percipiraju svoje pedagoške kompetencije za e-učenje u prosjeku u rasponu od 1,7 do 3,9, što ukazuje na njezinu moguću nedovoljnu razinu za primjenu e-učenja u hibridnome obliku na višoj razini. Najveći broj sudionika, njih 7 (63,7 \%), se slaže da je u mogućnosti upotrijebiti različite aplikacije (npr. testovi u Moodleu, Hot Po- 
tatoes, Lime Survey; Google Forms) te kreirati i primijeniti različite oblike online procjene znanja u svojem nastavnom radu. Nadalje, samo malo više od polovine ispitanika (6; 54,6 \%) smatra da su sposobni prepoznati osnovne mogućnosti različitih oblika nastave uz primjenu ICT-a u rasponu od (a) nastave podržane ICT-om u tradicionalnome okruženju, (b) hibridnoga/kombiniranoga oblika nastave do (c) u potpunosti online nastave. Zatim, jednako toliko njih se izjasnilo da su sposobni analizirati prikladnost različitih IKT (računalnih i internetskih) s obzirom na mogućnost primjene u odgojno-obrazovnome radu.

Također je iz dobivenih rezultata (Tablica 3.) vidljivo da sudionici - visokoškolski nastavnici u prosjeku $(M=1,7)$ smatraju da je uglavnom netočna tvrdnja da poznaju nekoliko modela instrukcijskoga dizajna koje mogu upotrijebiti pri kreiranju hibridnoga, odnosno virtualnoga okruženja za učenje (ADDIE, Dick \& Carey, ARCS ili neke druge), pri čemu se njih 9 (81,8 \%) izjasnilo da se u potpunosti ne slažu s navedenom tvrdnjom. Više od polovine ispitanika, njih 6 (54,5 \%), je iskazalo da se ne slažu s tvrdnjom da bi znali kod planiranja nastave učinkovito primijeniti načela različitih teorija učenja i poučavanja poput biheviorizma, kognitivizma, konstruktivizma ili drugih teorija u procesu e-obrazovanja. Nadalje, nešto manje od polovine ispitanika, njih 5 (45,4 \%), smatra da bi mogli uspješno voditi dugotrajnije online interakcije među studentima (npr. u web forumima i sl.), koristeći pritom nastavne metode i tehnike online moderiranja i mentoriranja (poticanje diskusija, motiviranje, pružanje podrške i sl.) te da su sposobni pripremiti, organizirati i postaviti online resurse kao podršku za sigurno provođenje aktivnosti online procjene znanja (kojim se sprečava prepisivanje, plagiranje i druge vrste varanja).

Samo jedna trećina ispitanika $(36,4 \%)$ uvjerena je da posjeduje potrebna pedagoško/didaktička znanja za e-učenje te je u mogućnosti primijeniti učinkovite nastavne tehnike i strategije za online poučavanje (kao primjer: rasprava/forum, samousmjereno učenje, suradničko učenje, učenje osnovano na projektima, rad u malim skupinama i sl.), zatim samo jednako toliko njih smatra da je u mogućnosti djelotvorno integrirati online nastavne aktivnosti u nastavni plan i program na osnovi analize potreba nastavnoga predmeta, karakteristika studenata i institucijskih činitelja te da je u mogućnosti primijeniti netradicionalne vrste procjena studenskoga znanja (kao primjer bodovanje sudjelovanja u diskusiji / na forumu, suradnju u wikiju i blogovima i sl.). Sudionici su u prosjeku $(M=2,9)$ odgovorili da se „ne slažu“ s tvrdnjom vezanom uz poznavanje standarda kvalitete e-obrazovanja prema kojima mogu evaluirati virtualno okruženje za učenje, pri čemu je samo njih 27,3 \% izjavilo da su upoznati sa standardima kvalitete e-obrazovanja. Također, samo se jedna trećina ispitanika, njih $36,4 \%$, slaže s tvrdnjom da su upoznati 
te da bi mogli primijeniti pravila i norme u pogledu intelektualnoga vlasništva nad obrazovnim sadržajem, kao i njihove zaštite u e-obrazovanju (Tablica 3.).

Tablica 3.: Broj (postotak) odgovora ispitanika (na stupnjevima od 1 - potpuno netočno do 5 - potpuno točno), aritmetička sredina (M) i standardna devijacija (s) vezana uz skalu „pedagoška kompetencija za primjenu IKT u hibridnoj nastavi“

$\begin{array}{llllllll}\text { Tvrdnje } & 1 & 2 & 3 & 4 & 5 & \text { M } \\ (\delta)\end{array}$

Sposoban/sposobna sam prepoznati osnovne mogućnosti različitih oblika nastave uz primjenu ICT-a u rasponu od (a) nastave podržane ICT-om u tradicionalnome okruženju, (b) hibridnoga/ kombiniranoga oblika nastave do (c) u potpunosti

$\begin{array}{cccccc}0 & 1 & 4 & 3 & 3 & 3,7 \\ (0,0) & (9,1) & (36,3) & (27,3) & (27,3) & (1,0)\end{array}$
online nastave.

Znao/znala bih kod planiranja nastave učinkovito primijeniti načela različitih teorija učenja i poučavanja, poput biheviorizma, kognitivizma, konstruktivizma ili drugih teorija u procesu

$\begin{array}{ccccc}0 & \mathbf{6} & \mathbf{3} & 0 & 2 \\ (0,0) & (\mathbf{5 4 , 5}) & (\mathbf{2 7}, \mathbf{3}) & (0,0) & (18,2)\end{array}$
e-obrazovanja.

Posjedujem potrebna pedagoško-didaktička znanja za e-učenje te sam u mogućnosti primijeniti učinkovite nastavne tehnike i strategije za online poučavanje (kao primjer: rasprava/forum, samousmjereno učenje, suradničko učenje, učenje osnovano na projektima, rad u malim skupinama

$\begin{array}{ccccc}0 & \mathbf{3} & \mathbf{4} & 2 & 2 \\ (0.0) & (\mathbf{2 7 , 3}) & (\mathbf{3 6 , 3}) & (18,2) & (18,2)\end{array}$
i sl.).

Poznajem nekoliko modela instrukcijskoga dizajna koje mogu upotrijebiti pri kreiranju hibridnoga, odnosno virtualnoga okruženja za učenje (ADDIE, Dick \& Carey, ARCS ili neke druge).

$\begin{array}{cccccc}\mathbf{9} & 0 & 0 & 0 & 2 & 1,7 \\ (\mathbf{8 1}, \mathbf{8}) & (0.0) & (0,0) & (0,0) & (18,2) & (1,6)\end{array}$

U mogućnosti sam analizirati prikladnost nastavnih materijala s obzirom na različite stilove učenja kod studenata te koristiti se nastavnim strategijama ili online aktivnostima koje su prilagođene različitim potrebama i stilovima učenja

$\begin{array}{ccccc}3 & 2 & 3 & 0 & 3 \\ (27,3) & (18,1) & (27,3) & (0,0) & (27,3)\end{array}$
2,8 mojih studenata.

Sposoban/sposobna sam analizirati prikladnost različitih ICT-a (računalnih i internetskih) s obzirom na mogućnost primjene u odgojnoobrazovnome radu.

$\begin{array}{cccccc}1 & 3 & 1 & \mathbf{3} & \mathbf{3} & 3,4 \\ (9,1) & (27,2) & (9,1) & (\mathbf{2 7}, \mathbf{3}) & (\mathbf{2 7 , 3}) & (1,4)\end{array}$

U mogućnosti sam djelotvorno integrirati online nastavne aktivnosti u nastavni plan i program na osnovi analize potreba nastavnoga predmeta $\mathrm{i}$ karakteristika studenata te institucijskih činitelja.

$\begin{array}{cccccc}0 & 2 & \mathbf{5} & 1 & 3 & 3,5 \\ (0,0) & (18,2) & (\mathbf{4 5 , 4}) & (9,1) & (27,3) & (1,1)\end{array}$

Mogao/mogla bih uspješno voditi dugotrajnije online interakcije medu studentima (npr. u web forumima i sl.) koristeći pritom nastavne metode i tehnike online moderiranja i mentoriranja (poticanje diskusija, motiviranje, pružanje podrške

$\begin{array}{cccccc}0 & 3 & 3 & 1 & \mathbf{4} & 3,5 \\ (0,0) & (27,3) & (27,3) & (9,1) & (\mathbf{3 6 , 3}) & (1,3)\end{array}$
isl.) 


\begin{tabular}{|c|c|c|c|c|c|c|}
\hline Tvrdnje & 1 & 2 & 3 & 4 & 5 & $\begin{array}{l}M \\
(\delta)\end{array}$ \\
\hline $\begin{array}{l}\text { U mogućnosti sam upotrebom različitih aplikacija } \\
\text { (npr. testovi u Moodleu, Hot Potatoes, Lime } \\
\text { Survey; Google Forms) kreirati te primijeniti } \\
\text { različite oblike online procjene znanja u svojem } \\
\text { nastavnom radu. }\end{array}$ & $\begin{array}{c}1 \\
(9,1)\end{array}$ & $\begin{array}{c}0 \\
(0,0)\end{array}$ & $\begin{array}{c}3 \\
(27,3)\end{array}$ & $\begin{array}{c}2 \\
(18,2)\end{array}$ & $\begin{array}{c}5 \\
45,5\end{array}$ & $\begin{array}{c}3,9 \\
(1,3)\end{array}$ \\
\hline $\begin{array}{l}\text { U mogućnosti sam primijeniti netradicionalne } \\
\text { vrste procjena studenskoga znanja (kao primjer } \\
\text { bodovanje sudjelovanja u diskusiji / na forumu, } \\
\text { suradnju u wikiju i blogovima i sl.) }\end{array}$ & $\begin{array}{c}1 \\
(9,1)\end{array}$ & $\begin{array}{c}3 \\
(27,3)\end{array}$ & $\begin{array}{c}3 \\
(27,3)\end{array}$ & $\begin{array}{c}0 \\
(0,0)\end{array}$ & $\begin{array}{c}4 \\
(36,3)\end{array}$ & $\begin{array}{c}3,3 \\
(1,5)\end{array}$ \\
\hline $\begin{array}{l}\text { Sposoban/sposobna sam pripremiti, organizirati } \\
\text { i postaviti online resurse kao podršku za sigurno } \\
\text { provođenje aktivnosti online procjene znanja } \\
\text { (kojim se sprečava prepisivanje, plagiranje i druge } \\
\text { vrste varanja). }\end{array}$ & $\begin{array}{c}0 \\
(0,0)\end{array}$ & $\begin{array}{c}1 \\
(9,1)\end{array}$ & $\begin{array}{c}5 \\
(45,4)\end{array}$ & $\begin{array}{c}2 \\
(18,2)\end{array}$ & $\begin{array}{c}3 \\
(27,3)\end{array}$ & $\begin{array}{c}3,6 \\
(1,0)\end{array}$ \\
\hline $\begin{array}{l}\text { Poznajem standarde kvalitete e-obrazovanja prema } \\
\text { kojima mogu evaluirati virtualno okruženje za } \\
\text { učenje. }\end{array}$ & $\begin{array}{c}2 \\
(18,2)\end{array}$ & $\begin{array}{c}2 \\
(18,2)\end{array}$ & $\begin{array}{c}4 \\
(36,3)\end{array}$ & $\begin{array}{c}1 \\
(9,1)\end{array}$ & $\begin{array}{c}2 \\
(18,2)\end{array}$ & $\begin{array}{c}2,9 \\
(1,4)\end{array}$ \\
\hline $\begin{array}{l}\text { Imajući u vidu kreiranje i korištenje online } \\
\text { resursa za e-učenje, poznajem i mogao/mogla } \\
\text { bih primijeniti pravila i norme u pogledu } \\
\text { intelektualnoga vlasništtva nad obrazovnim } \\
\text { sadržajem, kao i njihove zaštite. }\end{array}$ & $\begin{array}{c}1 \\
(9,1)\end{array}$ & $\begin{array}{c}2 \\
(18,2)\end{array}$ & $\begin{array}{c}4 \\
(36,3)\end{array}$ & $\begin{array}{c}1 \\
(9,1)\end{array}$ & $\begin{array}{c}3 \\
(27,3)\end{array}$ & $\begin{array}{c}3,3 \\
(1,3)\end{array}$ \\
\hline
\end{tabular}

\section{ZAKLJUČAK}

Danas je razvoj e-obrazovanja imperativ za mnoge visokoškolske ustanove koje ulažu napore u internacionalizaciju radi postizanja više razine tržišne konkurentnosti. U ovome je radu poseban naglasak dan na hibridni oblik e-učenja s obzirom na to da je to jedan od najčešće korištenih modela na visokoškolskim ustanovama, zbog njihove prirode organizacije. Ključna barijera u razvoju e-učenja je nedovoljna prihvaćenost e-učenja od strane visokoškolskih nastavnika koji moraju nadopuniti svoje nastavničke kompetencije s kompetencijama za e-učenje. Posebnost kompetencija za e-učenje u hibridnome obliku ogleda se u nastavničkome spajanju kompetencija za e-učenje i kompetencija za poučavanje u tradicionalnoj učionici. Stoga se smatra da je razvoj nastavničkih kompetencija za e-učenje od izuzetne strateške važnosti za primjenu u hibridnome okruženju za učenje za sve visokoškolske ustanove.

Sudionici su se u ovome istraživanju izjasnili da je većina njih dotad izradila barem jedan online tečaj/kolegij za potrebe svojega nastavnog rada, zatim da su svoja znanja, vještine i sposobnosti podjednako stjecali iz tehničkoga te tehničkoga i pedagoškoga korištenja IKT-a u nastavi, nadalje najveći broj ispitanika su svoja znanja, vještina i sposobnosti iz područja e-obrazovanja stjecali samoedukacijom 
koristeći dostupne vodiče, literaturu te je dotad najmanje njih za e-učenje upotrebljavalo videokonferencije i webinare. Navedeno potvrđuje da su ispitanici u ovome istraživanju dotad primjenjivali e-učenje u svojem nastavnom radu većim udjelom samo na osnovnoj razini.

U osnovici e-učenje se može promatrati s tehničkoga i pedagoškoga aspekta, stoga su za primjenu e-učenja u visokoškolskoj nastavi potrebna IKT znanja i vještine te pedagoška kompetencija upotrebe IKT-a u nastavi. Rezultati istraživanja u ovome su radu pokazali da su svoja znanja iz e-učenja nastavnici u prosjeku ocijenili vrlo dobrom ocjenom. S obzirom na to da su ispitanici stručnjaci u informatici, svoja IKT znanja i vještine su u prosjeku ocijenili vrlo dobrom do odličnom ocjenom, pri čemu su ocijenili da nešto manje raspolažu sa znanjima iz kreiranja npr. videozapisa te korištenja wiki alata. $\mathrm{S}$ druge strane, rezultati istraživanja su pokazali da nastavnici raspolažu nižom razinom pedagoškoga znanja, kao što su: poznavanje modela instrukcijskoga dizajna, teorije učenja i poučavanja, percepcija prikladnosti nastavnih materijala sobzirom na različite stilove učenja kod studenata, metode i tehnike online moderiranja i mentoriranja, primjena netradicionalnih vrsta procjena studenskoga znanja (kao primjer bodovanje sudjelovanja u diskusiji I na forumu, suradnju u wikiju i blogovima i sl.), standarde kvalitete e-obrazovanja, pravila i norme u pogledu intelektualnoga vlasništva nad obrazovnim sadržajem $i$ drugo. Budući da rezultati istraživanja pokazuju da su znanja iz e-učenja nastavnici ocijenili u prosjeku vrlo dobrom ocjenom, navedeno dozvoljava zaključak da su nastavnici pritom e-učenje promatrali više s tehničkoga aspekta, što može biti značajna barijera u primjeni e-učenja na višoj razini u hibridnoj nastavi te u konačnici razvoja kvalitete e-obrazovanja na visokoškolskoj instituciji.

Dobiveni rezultati istraživanja u ovome su radu potvrdili rezultate prethodnih istraživanja koje su proveli Babić i Bubaš (2015), Babić (2016) i drugi. Ovo istraživanje ima određena ograničenja koja se mogu primijetiti kod maloga broja sudionika. Međutim, treba naglasiti da su sudionici ovoga istraživanja bili stručnjaci u informatici. Rezultati ovoga istraživanja imaju različite praktične i znanstvene implikacije. U praksi, ovi rezultati mogu poslužiti realizatorima obrazovnih strategija i politika te svima onima kojima je cilj razvoj kvalitete e-obrazovanja na visokoškolskim institucijama i šire, dok znanstvenici mogu koristiti rezultate istraživanja i upitnik kao osnovu za daljnja istraživanja u svojim obrazovnim okruženjima. 


\section{LITEARATURA}

1. Akar, M., Güzin, S. (2019). A Structural Model for Relationship between Web Pedagogic Content Knowledge and Technology Acceptance of Preservice Teachers. Malaysian Online Journal of Educational Technology, 7(1): 1-14.

2. Alhabeeb, A., Rowley, J. (2018). E-learning critical success factors: Comparing perspectives from academic staff and students. Computers \& Education, 127: 1-12.

3. Al-Samarraie, H., Teng, B. K., Alzahrani, A. I., Alalwan, N. (2018). E-learning continuance satisfaction in higher education: a unified perspective from instructors and students. Studies in higher education, 43(11): 2003-2019.

4. Altin, M. E. (2019). Internationalization of the German Higher Education System New Player in the Market. Athens Journal of Education, 6(3): 237-256.

5. Babić, S. (2009). Competencies and attitudes of university teachers related to their acceptance of elearning technology. U: Čičin-Šain i sur. (ur.), Proceedings of the Conference Computers in Education, 32th International Convention MIPRO 2009 (312-317), Opatija: MIPRO Croatian Society

6. Babić, S., Bubaš, G. (2015). Assessment of competencies of online teachers: pilot study and survey evaluation. U: T. Cirić, S. Jovanović (ur.), Proceedings of the 6th International Conference on e-Learning 2015 (164-171), Belgrade: Metropolitan University

7. Babić, S. (2016). Činitelji nastavničkoga prihvaćanja e-učenja i kompetencije za njegovo korištenje u visokoškolskim ustanovama, Doctoral dissertation, Fakultet organizacije i informatike, Varaždin, Sveučilište u Zagrebu.

8. Bierne, J., Svirina, A., Titko, J. (2018). E-Learning and E-Teaching Effectiveness: Academic Staff Perception. U: International Conference on Reliability and Statistics in Transportation and Communication (768-778), Springer, Cham.

9. Ehlers, U. D., Kellermann, S. A. (2019). Future Skills: The future of learning and higher education (2-69), Karlsruhe.

10. Gunasinghe, A., Hamid, J. A., Khatibi, A., Azam, S. M. (2018). Does the Lecturer's Innovativeness Drive VLE Adoption in Higher Education Institutes? (A Study Based on Extended UTAUT). Journal of Information Technology Management, 10(3): 20-42.

11. Jokiaho, A., May, B., Specht, M., Stoyanov, S. (2018). Barriers to using E Learning in an Advanced Way. International Journal of Advanced Corporate Learning (iJAC), 11(1): 17-22.

12. Martín-García, A. V., Martínez-Abad, F., Reyes-González, D. (2019). TAM and stages of adoption of blended learning in higher education by application of data mining techniques, 50(5), British Journal of Educational Technology. doi:10.1111/bjet.12831

13. Rogers, E. M. (1995). Diffusion of innovations, 4th ed. New York: Free Press.

14. Sinclair, J., Aho, A. M. (2018). Experts on super innovators: understanding staff adoption of learning management systems. Higher Education Research \& Development, 37(1): 158-172. 


\title{
THE IMPORTANCE OF HIGHER EDUCATION TEACHERS E-LEARNING COMPETENCES DEVELOPMENT FOR HYBRID LEARNING ENVIRONMENT
}

\begin{abstract}
Under the influence of various aspects, higher education institutions are increasingly investing in the development of different e-learning models, including hybrid learning environments. The results of previous research have shown that the adoption of e-learning by higher education teachers depends on the level of their e-learning competences. The aim of this paper was to highlight the importance of developing higher education teachers e-learning competencies for applying hybrid learning environments, by showing the research results at Faculty of Informatics, University of Pula. The research findings in this paper show that higher education teachers using e-learning are mostly selfeducated for e-learning usage, have a high level of ICT knowledge and skills and do not have enough pedagogical knowledge to apply the hybrid learning environment at a more advanced level. The results can be used by those interested in the development of e-learning in higher education institutions and beyond.
\end{abstract}

Key words: higher education teachers, ICT knowledge and skills, e-learning pedagogical competence, hybrid learning environment. 